\title{
The Effect of Corporate Social Responsibility Factor on the Sustainable Development of Industrial SMEs: A Case Study in Hanoi-Vietnam
}

\author{
Hung Do Hai*, Cung Nguyen Huu \\ School of Business Management, Hanoi University of Industry, Vietnam \\ *Corresponding author \\ dohaihung@haui.edu.vn,dohaihunghaui@gmail.com
}

\begin{abstract}
Implementing social responsibility activities (CSR) towards sustainable development (Sustainable Development) is one of the issues that businesses pay special attention. The study selected research scope in Hanoi, Vietnam. Applying qualitative and quantitative methods to evaluate the influence and the degree of influence of the corporate social responsibility factor on the sustainable development of industrial small and medium enterprises (SMEs) in Hanoi, Vietnam. The study carried out a survey of 182 industrial SMEs allocated according to different business sectors and territories in Hanoi. The research results showed that the social activities of enterprises have a positive influence on the sustainable development of industrial small and medium-sized enterprises in Hanoi, besides other factors such as: Conscious innovation; Finance; Human resources; Local support policies and the manufacturing.

Objectives of the study: This study aims to evaluate the impact of corporate social responsibility factors on the sustainable development of small and medium industrial enterprises in Hanoi, among other factors such as: Manufacturing technology; Business's resource enterprises; Innovation; Local support policies.
\end{abstract}

Keyword-Sustainable Development; Industrial SMEs; Social Responsibility

\section{INTRODUCTION}

$\mathrm{F}$ ACING the trend of extensive international integration, the issue of sustainable development in general and enterprise's sustainable development in particular in recent years has always been given special attention by state management agencies. Implementing sustainable development is the responsibility of the whole society, including the contribution of the enterprise community. However, to further promote the development of enterprises towards sustainability, the role of the enterprise's CSR activities should be considered [1].

In Vietnam, according to the annual report of Vietnam Enterprises 2018/2019 of Vietnam Chamber of Commerce and Industry (VCCI) in terms of classification of small and medium-sized enterprises according to the Government's Decree No. 39, according to the labor size: Medium enterprises with the number of 8,518 enterprises, accounting for $1.58 \%$; small enterprises with the number of 115,235 enterprises, accounting for $21.35 \%$; and micro enterprises with the number of 415,835 enterprises, accounting for $77.07 \%$. The proportion of SMEs now accounts for $97.8 \%$ of the total number of enterprises in Vietnam [2],[3],[4]. Ha Noi is one of two largest cities in Viet Nam. The total number of enterprises in Ha Noi by the end is over 150,000 enterprises in 2019. In which SMEs account for approximately $98 \%$ of the total enterprises number, the number of industrial enterprises accounts for about $20 \%$ of the total SMEs number. In order to promote industrial SMEs in Ha Noi to maintain and develop more towards sustainable development [5].

The characteristics of SMEs are the limited amount of products, mainly base on manual labor, SMEs, usually only sell a few products and services in compliance with the qualifications and experience as well as finance capacity of business owners; The business capital of SMEs is mainly owned by the business owners, or borrowed from business owners relatives and friends, and the ability to access capital from credit institutions is low; SMEs are flexible due to low initial investment, use few labor and local resources. Therefore, SMEs can easily change their production plans, convert their business premises, change their business type and even easily dissolve their businesses; SMEs are established and operated mainly based on the capacity and experience of the business owners themselves, so the organization of the apparatus is very compact and management decisions are also quickly implemented [6]. Stemming from the characteristics of industrial SMEs in Vietnam and Hanoi now, it can be seen that, in the long term, the sustainable development of industrial small and medium enterprises in Hanoi is necessary and consistent with the general development trend of the world when international integration in countries are more extensive. The inherent characteristics of industrial SMEs in Hanoi currently mentioned above such as: limited capital, backward production technology, poor infrastructure will heavily affect labor productivity or problems in addressing environmental pollution and contribute to the overall development of society [7]. These barriers need to be thoroughly overcome in order to promote the industrial small and medium enterprises in Hanoi towards sustainable.

The development of enterprises depends on available resources, the issue of community benefits, solving environmental pollution in the production process is really necessary for businesses. In order to promote industrial small and medium-enterprises in Hanoi maintaining and developing towards sustainable development, study that assess the impact and impact level of CSR policies to the sustainable development of industrial small and medium - sized enterprises is essential in the current situation of industrial SMEs in Hanoi. Through the research results, the author proposes a number of solutions and recommendations for enterprises 
and state management agencies to maintain and promote the sustainable development of industrial SMEs on a wider scale and more quality.

\section{LITERATURE REVIEW}

According to the World Business Council for Sustainable Development [8], sustainable businesses can be interpreted as corporate commitment to conduct ethically and contribute to economic development, while improving workforce's quality of life, their families, local and global communities in both the present and future. Therefore, in respect to SME sustainability, it covers most aspects of economy, social attitudes, safety and the environment [9].

As for the Corporate Social Responsibility (CSR) policy, first published in 1953 by HRBowen, the policy was designed to propagate and appeal to managers stop harming the rights and benefit of others, calling for charity to compensate for damages caused by businesses that harm society. Since then, the term corporate social responsibility has been interested by many researchers and given different points of view. D. Wood (2010) said that CSR is difficult to define, different objects understand different CSR. Each industry, organization, and government views CSR from a different point of view, so there are many different definitions of corporate CSR [10],[11]. Despite the lack of a consistent definition, all definitions show that the company should meet social expectations when planning environmental management strategies [12]. Carroll (1979, 1991) stated that: "Social responsibility is all the economic, legal, ethical and charitable issues of an organization that society expects from a given time." This is a concept that has been widely used in social responsibility studies, depending on which organization an administrator can choose from among the four levels [13]. Mujahid and Abdullah (2014) pointed out that CSR has a positive and significant influence on the financial performance of businesses as well as the wealth of share holders. In this same view, Kiran et al. (2015) emphasized, there exists a close relationship between social responsibility and profitability of enterprises; The study identified three main issues: (i) social responsibility has a positive impact on net profit and net profit margin; (ii) social responsibility has a negative impact on the total assets of the enterprise; and (iii) social responsibility has no significant effect on the profitability of the business. Research by [14] stated that social responsibility included the following components: CSR for social and non-social stakeholders (e.g. Environment or future generation), CSR for employees, CSR for customers and CSR for the government. According to him, the social activities of businesses related to these components would affect the level of employee engagement with the organization through social identity theory (SIT). Research results showed that CSR for employees has the greatest impact on employee engagement with the organization because it is related to careers, training opportunities, equality and working environment. CSR for customers has the second highest level of influence because it relates to the image of the organization, thus affecting the pride of the employees for the organization. Next is CSR for stakeholders (social and non-social). Finally, social responsibility to the government. Social responsibility will also create credibility for businesses with customers, investors, suppliers and governments. Thereby positively influencing decision making in favor of SMEs. CSR also brings competitive advantages, thereby affecting the efficiency of business operations of the organization. Organizations can enhance employee engagement by promoting socially beneficial activities. [15]

In general, the basic studies have emphasized the role of the implementation of social responsibility for the development and sustainable development of industrial small and medium sized enterprises. Considering the scope of research Hanoi, this issue has not been reviewed and evaluated in detail. Therefore, this study is necessary to assess the role and impact of social responsibility performance compared to other factors affecting the sustainable development of industrial small and medium-sized enterprises (SMEs) in Hanoi.

\section{PROPOSED WORK}

\section{A. Questionnaire and Data collection}

In this study, raw data collection was conducted through in-depth interviews with experts and managers in industrial SMEs in Vietnam to develop an official questionnaire. The questionnaire consists of 3 parts. The first part information is details of respondents, part 2 is information related to the characteristics of the business, part 3 is the questions related to the factors affecting the sustainable development of industrial SMEs. The data collection is done through convenient sampling methods to collect feedback data of business managers on the impact of the corporate social responsibilities on the sustainable development of industrial SMEs in Hanoi.

The questionnaire uses the Rennis Likert scale (also known as the Likert scale), the Likert scale has 5 levels from low to high scores, ranging from 1-5 as follows: 1. Strongly disagree; 2. Disagree; 3. Normal; 4. Agree; 5. Strongly agree.

The total number of questionnaires issued is 225 , collecting 205 feedbacks, the number of valid feedbacks for data processing is 182 .

\section{B. Data analysis}

The raw data will be processed in SPSS 23.0 software after being collected. The study tested the reliability of a scale using Cronbach's Alpha coefficient, which is a statistical test of the degree of rigor with which the items in the scale correlate. Then, conduct Exploratory Factor Analysis (EFA) to check the unidirectional of the scales in the study. Finally, the study uses multivariate regression methods to evaluate the impact of the corporate social responsibility compared to the following factors: Conscious innovation; Business's resources; Support policies from the 
government and the manufacturing factor to the sustainable development of industrial SMEs in Hanoi.

\section{Research Models}

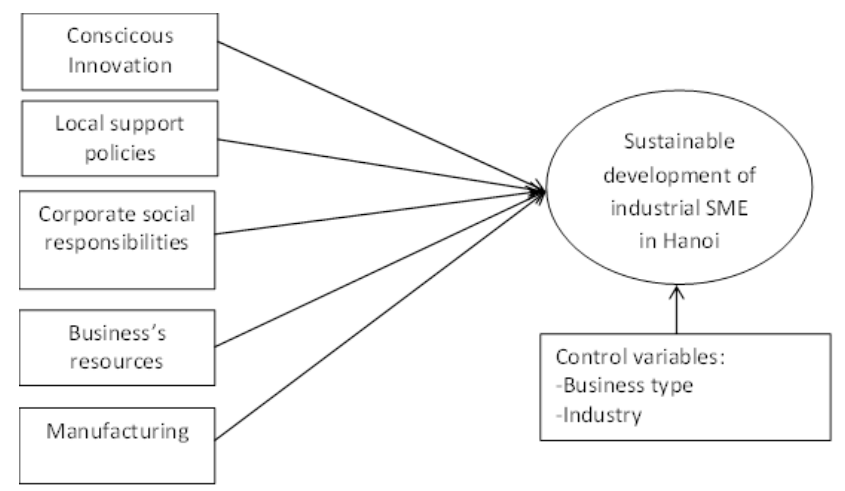

Figure 1. Research Model

\section{Research hypotheses:}

Hypothesis H1: The conscious innovation has a positive influence on the sustainable development of SMEs in Hanoi.

Hypothesis H2: The manufacturing has a positive affecting the sustainable development of SMEs in Hanoi.

Hypothesis H3: Operational factors of corporate social responsibility have a positive influence on the sustainable development of SMEs in Hanoi.

Hypothesis H4: The resources of enterprises have a positive influence on the sustainable development of SMEs in Hanoi.

Hypothesis H5: The local support policies have a positive influence on the sustainable development of SMEs in Vietnam.

Table 1. Measurement scale and construction source

\begin{tabular}{|c|c|c|c|}
\hline Scale & Encode & Question & Source \\
\hline \multirow{4}{*}{$\begin{array}{l}\text { Conscious } \\
\text { innovation }\end{array}$} & YT1 & The initiatives in the business have recorded & \multirow{4}{*}{$\begin{array}{l}\text { Quintero-Angel, M et } \\
\text { al(2018) [16], Farsi, J. Y } \\
\text { et al (2014) [17] và } \\
\text { nghiên cứu của tác giả }\end{array}$} \\
\hline & YT2 & Business leaders are willing to take risks and fail & \\
\hline & YT3 & Enterprises have the incentive mechanism for incentives applied in reality & \\
\hline & YT4 & Enterprises always focus on high - tech applications in production activities & \\
\hline \multirow{6}{*}{$\begin{array}{l}\text { Local support } \\
\text { policies }\end{array}$} & CS1 & Accessing the production premises easily & \multirow{6}{*}{$\begin{array}{l}\text { Le Ngoc Nuong (2018) } \\
{[18] \text { and Author's }} \\
\text { proposal }\end{array}$} \\
\hline & $\mathrm{CS} 2$ & Supported to participate in social activities & \\
\hline & CS3 & No difficulty in handling administrative procedures & \\
\hline & CS4 & Preferential tax policies in production and business activities & \\
\hline & CS5 & $\begin{array}{l}\text { Enterprises are informed the change of environmental protection policy } \\
\text { promptly }\end{array}$ & \\
\hline & CS6 & Accessing credit resources supported by the Government easily & \\
\hline \multirow{6}{*}{$\begin{array}{l}\text { Operational factors } \\
\text { of corporate social } \\
\text { responsibility }\end{array}$} & TN1 & $\begin{array}{l}\text { Participating vocational training programs for young people in the } \\
\text { community }\end{array}$ & \multirow{6}{*}{$\begin{array}{l}\text { Phan Van Dan (2012) } \\
\text { [19]; Duyg u. T (2008) } \\
\text { and Author's proposal }\end{array}$} \\
\hline & TN2 & $\begin{array}{l}\text { Participating in construction of clean water and sanitation programs for the } \\
\text { community }\end{array}$ & \\
\hline & TN3 & $\begin{array}{l}\text { Participating in training, improving capacity and social knowledge for the } \\
\text { workers }\end{array}$ & \\
\hline & TN4 & Participating in contribution of social activities in the locality & \\
\hline & TN5 & $\begin{array}{l}\text { Focusing and paying attention on issues of environmental pollution } \\
\text { treatment }\end{array}$ & \\
\hline & TN6 & $\begin{array}{l}\text { Complying with the provisions of the law on ensuring food and } \\
\text { environmental safety }\end{array}$ & \\
\hline \multirow{5}{*}{$\begin{array}{l}\text { The resources of } \\
\text { enterprises }\end{array}$} & NL1 & Current financial resources are sufficient to expand business activities & \multirow{5}{*}{$\begin{array}{l}\text { Umar Ibrahim (2008) } \\
{[20] \text { and Trinh Duc }} \\
\text { Chieu (2010) [5] }\end{array}$} \\
\hline & NL2 & Current financial resources are sufficient to sustain the business activities & \\
\hline & NL3 & Human resources in enterprises have good working capacity & \\
\hline & NL4 & $\begin{array}{l}\text { Annually, the number of qualified employees in the enterprise is becoming } \\
\text { higher and higher }\end{array}$ & \\
\hline & NL5 & After training, labor is more productive & \\
\hline \multirow{5}{*}{$\begin{array}{l}\text { Manufacturing } \\
\text { technology }\end{array}$} & CN1 & Prioritize in investing to renew equipment annually & \multirow{4}{*}{\begin{tabular}{lr} 
Asma & \multicolumn{2}{c}{ Benzazoua } \\
Bouazza & $(2015)$ \\
Sefiani $(2013)[21]$
\end{tabular}} \\
\hline & $\mathrm{CN} 2$ & Manufacturing technology is top priority & \\
\hline & $\mathrm{CN} 3$ & Develop a new product development strategy & \\
\hline & $\mathrm{CN} 4$ & Focus on human resource investment to apply new technologies & \\
\hline & BV1 & Enterprises always have high profits and grow steadily every year & \\
\hline
\end{tabular}




\begin{tabular}{|c|c|c|c|}
\hline Scale & Encode & Question & Source \\
\hline \multirow{5}{*}{$\begin{array}{l}\text { The sustainable } \\
\text { development of } \\
\text { SMEs in Hanoi }\end{array}$} & BV2 & Enterprises can expand production and business markets & \multirow{5}{*}{$\begin{array}{l}\text { Phan Van Dan (2012) } \\
{[19] \text { and Author's }} \\
\text { proposal }\end{array}$} \\
\hline & BV3 & Enterprises are recorded for environmental protection in production & \\
\hline & BV4 & $\begin{array}{l}\text { Enterprises have made positive contributions to local environmental } \\
\text { protection activities }\end{array}$ & \\
\hline & BV5 & $\begin{array}{l}\text { Enterprises are always highly appreciated by local agencies for their } \\
\text { contribution to local social activities }\end{array}$ & \\
\hline & BV6 & Enterprises always create motivation to work for labor & \\
\hline
\end{tabular}

(Source: Summary of the authors)

\section{Results AND Discussion}

\section{A. Verify the reliability of the scale}

The reliability of scales is assessed by Cronbach's Alpha coefficient. Results of calculating Cronbach's Alpha coefficients with each concept indicate that 5 groups of research elements have Cronbach's Alpha coefficient greater than 0.6 (Table 2). All observed variables have varied-total correlations meeting the requirement of $>0.4$, expect the YT2 observations have a correlation coefficient that transforms slightly less than 0.4 (value of total correlation is 0.255 ), which is excluded from the research model. Therefore, the manufacturing factor scale and three other factors scale affecting the sustainable development of industrial SMEs in Hanoi - Vietnam are eligible for EFA analysis.

\section{B. Exploratory Factor Analysis}

The results of the EFA's all factors affecting the sustainable development of industrial SMEs in Hanoi produce the value of KMO (Kaiser-Meyer-Olkin) $=0.761>0.6$. Therefore, factor analysis is consistent with the research data obtained. The Bartlett's test value with the hypothesis (H0) is "non-correlated variables" with the value $\mathrm{Sig}=0.00<0.05$.

Table 2. Results of EFA's factors and evaluation of reliability of the scale

\begin{tabular}{|c|c|c|c|c|c|c|c|}
\hline \multirow{2}{*}{ Factors } & \multicolumn{7}{|c|}{ Factor Loading } \\
\hline & 1 & 2 & 3 & 4 & 5 & 6 & 7 \\
\hline Cronbach's Alpha & 0.756 & 0.728 & 0.783 & 0.752 & 0.712 & 0.701 & 0.795 \\
\hline $\mathrm{CN} 1$ & 0.782 & & & & & & \\
\hline $\mathrm{CN} 4$ & 0.689 & & & & & & \\
\hline $\mathrm{CN} 3$ & 0.615 & & & & & & \\
\hline $\mathrm{CN} 2$ & 0.526 & & & & & & \\
\hline $\mathrm{CS} 3$ & & 0.765 & & & & & \\
\hline $\mathrm{CS} 2$ & & 0.722 & & & & & \\
\hline CS1 & & 0.701 & & & & & \\
\hline CS6 & & 0.652 & & & & & \\
\hline CS5 & & 0.582 & & & & & \\
\hline CS4 & & 0.526 & & & & & \\
\hline TN2 & & & 0.735 & & & & \\
\hline TN1 & & & 0.675 & & & & \\
\hline TN3 & & & 0.632 & & & & \\
\hline TN4 & & & 0.568 & & & & \\
\hline TN6 & & & 0.452 & & & & \\
\hline TN5 & & & 0.438 & & & & \\
\hline NL1 & & & & 0.746 & & & \\
\hline NL2 & & & & 0.664 & & & \\
\hline NL3 & & & & & 0.781 & & \\
\hline NL4 & & & & & 0.765 & & \\
\hline NL5 & & & & & 0.695 & & \\
\hline YT1 & & & & & & 0.652 & \\
\hline YT4 & & & & & & 0.586 & \\
\hline YT3 & & & & & & 0.485 & \\
\hline BV1 & & & & & & & 0.836 \\
\hline BV3 & & & & & & & 0.807 \\
\hline BV4 & & & & & & & 0.786 \\
\hline BV2 & & & & & & & 0.761 \\
\hline BV5 & & & & & & & 0.745 \\
\hline
\end{tabular}




\section{Regression analysis}

Regression analysis value of $\mathrm{R}=$ results in the 0.562 and adjusted R2 is 0.525 . This means that the relationship between the independent variables explains $52.5 \%$ of the dependent variable as "Sustainable development of industrial small and medium enterprises in Hanoi". Through ANOVA analysis results, the value of $F=62,322$ with statistical significance $\mathrm{Sig}=0.0015<0.05$. It can be confirmed the existence of relationships between independent variables and dependent variables. Thereby, showing that the research model ensures reliability.

Based on the Beta coefficient in Table 3, it can be seen that the factors in the research model, the Manufacturing technology $(\mathrm{CN})$ factor have the largest Beta standardization factor $=0.296$. Social resp $(\mathrm{TN})$ factor has the smallest Beta coefficient $=0.1122$. Sig value. of all variables $<0.05$. Therefore, the hypotheses H1, H2, H3 and H4 proposed in the research model are all accepted. The non-standardized regression model of factors affecting the sustainable development of industrial SMEs in Vietnam is determined as follows:

$$
\begin{array}{r}
\mathrm{BV}=-1,242+0,289 * \mathrm{CN}+0,265 * \mathrm{TC}+0,135 * \mathrm{TN} \\
+0,189 * \mathrm{CS}+0,166 * \mathrm{NL}+0,104 * \mathrm{YT}
\end{array}
$$

Table 3. Beta coefficient after performing regression

\begin{tabular}{|c|c|c|c|c|c|}
\hline & \multicolumn{2}{|c|}{$\begin{array}{c}\text { Non- } \\
\text { standardized } \\
\text { coefficient }\end{array}$} & $\begin{array}{c}\text { Standardize } \\
\text { d coefficient }\end{array}$ & $\begin{array}{c}\text { Validation } \\
\text { value t }\end{array}$ & $\begin{array}{c}\text { Level of } \\
\text { significance } \\
\text { Sig. }\end{array}$ \\
\cline { 2 - 4 } & B & $\begin{array}{c}\text { Standard } \\
\text { error }\end{array}$ & Beta & & \\
\hline Constant & $-1,242$ & 0,216 & & $-4,221$ & 0,000 \\
\hline CN & 0,531 & 0,063 & 0,289 & 6,227 & 0,000 \\
\hline CS & 0,422 & 0,052 & 0,189 & 5,351 & 0,001 \\
\hline NL & 0,158 & 0,045 & 0,166 & 3,462 & 0,011 \\
\hline TC & 0,124 & 0,058 & 0,265 & 3,421 & 0,002 \\
\hline TN & 0,292 & 0,039 & 0,135 & 4,421 & 0,001 \\
\hline YT & 0,232 & 0,028 & 0,104 & 3,252 & 0,002 \\
\hline
\end{tabular}

Source: SPSS23.0 data processing results of the authors.

Based on the regression equation (1), it can be seen that the manufacturing technology factor $(\mathrm{CN})$ has the greatest impact on the sustainable development of industrial small and medium enterprises in Hanoi. Next are the factors is finance resources of enterprises (TC), factor of the local support policies (CS), factor of human resources, activities of social responsibility (TN) and finally the concious innovation (CS). It can be seen that the corporate social responsibility activity has a positive influence and the fourth effect in the author's research model, behind human resource factors, finance, concious innovation, local support policies and manufacturing technology.

The research results are similar to those of Phan Van Dan (2012), Quintero - Angel et al(2018) and Le Ngoc Nuong (2018). In Le Ngoc Nuong's study (2018), the local support policies have the fourth most powerful influence and the $1^{\text {st }}$ strong manufacturing technology factor out of the 7 factors that have an impact on the development of small industrial enterprises and fit. However, the research results are not similar to abraham\&moitra (2001)' s research and wang et al (2008), the corporate social responsibilty and concious innovation factors have the lowest impact on the sustainable development of the industrial SMEs. This can be explained that the industrials SMEs in Hanoi, it is characterized by limited resources, small production, so they are not focused and interested the corporate social responsibilty and concious innovation ideas. The situation of the long - term development of industrials SMEs in Vietnam and in particular in Hanoi is now the backward production level, barriers to administrative procedures and local support are not really good. Therefore, the results of the research report show that the factors of manufacturing technology, local support policies and finance resources is the most affect to the sustainable development of industrials SMEs in Hanoi, it's suitable for research practice.

\section{Testing statistical hypotheses}

Using Anova's variance analysis to determine the differences of types of businesses and industries participating in the survey. In this analysis, the coefficient of concern is the Sig coefficient. The hypothesis $\mathrm{H} 0$ poses is that there is no difference in the sustainable development of enterprises by business sector and type of enterprise. If the Sig coefficient is $>0.05$, reject the $\mathrm{H} 0$ hypothesis, which means that there is a difference in the type of business and business lines in the field of SMEs development in Hanoi. If Sig $<0.05$, accept hypothesis $\mathrm{H} 0$.

The testing results of all groups of enterprises by type and business lines give Sig value $<0.05$. Specifically, testing the differences by type of enterprise has a value of $\mathrm{Sig}=0.011$; Testing difference by business lines has value of $\mathrm{Sig}=$ 0.002 . Therefore, reject the H0 hypothesis.

According the research results, it can be seen that the factors of manufacturing technology and financial are the two most influential factors for the sustainable development of Industrial SMEs in Hanoi. This result is consistent with the current characteristics of Industrial SMEs in Hanoi when the most of them have limited financial resources, the production scale is small and out of date. In particular, for the social responsibility factor, the research results have shown that this factor positively affects the sustainable development of industrial SMEs and the level of influence is higher than the innovation consciousness. It can be argued that the implementation of social responsibility is a mandatory requirement for businesses in the process of moving towards sustainable development. Before businesses move towards innovation and creativity, it is necessary to perform well the responsibilities of the business to the employees in the organization and make a positive contribution to the community.

\section{CONCLUSION AND FUtURE WORK}

Through the research results, the authors propose a number of solutions and recommendations for the policies on 
corporate social responsibility for the sustainable development of industrial SMEs in Hanoi, specifically as follows: Firstly, businesses need to build a system of specific rules and regulations on the salary and bonus regime for employees, ensuring fairness in the company. Besides, it is necessary to create a safe working environment in the aspects of food safety, fire safety, fire safety and human rights.

Secondly, strengthen the role of the industrial SME Association in Hanoi and other association in Vietnam, and to promote the development and cohesion between industrials SMEs. Supporting and promoting the propaganda and education for businesses about social responsibility and the meaning of local social activities. In addition, through these associations, businesses can timely access new policies, new legal documents of the State on sustainable development.

Third, strengthening the deployment of supporting activities and associating training with educational and training institutions to improve the quality of local human resources and human resources in enterprises. Business managers must be a bridge between local human resources, human resources in enterprises and quality education and training institutions to coordinate the deployment of more training courses for knowledge and skills for workers, thereby promoting the quality of human resources in the community of businesses and localities more and more developed.

Through the research results, it was shown that the social responsibility factor has a positive impact on the sustainable development of industrials SMEs in Hanoi, but the level of influence isn's as big as the manufacturing technology, finance or the local support policies. The research results are consistent with the current practice in Hanoi when the industrials SMEs have large limitations on manufacturing technology and finance resources and activities on implementation of social responsibility have not been focused.

The research still has some limitations when the sample size is not large, the research only stops the scope of research in Hanoi. In subsequent studies, the authors will expand the scope of the study and the wider sample size to determine more specifically the extent of factors affecting the sustainable development of industrials SMEs in Vietnam.

\section{REFERENCES}

[1] Baker. S, 1997. The Politics of Sustainable Development. London, Routledge.

[2] General Statistics Office of Vietnam, 2019
[3] Viet Nam Enterprises Law, 2014. No. 68/2014/QH13

[4] Ministry of sustainable development targets of enterprises, 20172019. Viet Nam Chamber of Commerce and Industry (VCCI).

[5] Do Hai Hung, Than Thanh Son, (2020). Study on the effect of manufacturing technology factor on the sustainable development of industrial SMEs in Hanoi. Advances in Management \& Applied Economics, Vol.10, No.4,35-45.

[6] Trinh Duc Chieu, 2010. The impact factor influence to growth of small and medium enterprises in Viet Nam, Government Economics Research.

[7] Phung The Dong, 2019, Supporting Vietnam's small and mediumsized enterprises in their current development. Finance Journal, No.11.

[8] Watts,P., \& Holme, R (1999). Corporate social responsibility: Meeting changing expectations. World Business Council for Sustainable Development.

[9] Mina Rafiei and Luis A. Ricardez-Sandoval (2020). New frontiers, challenges, and opportunities in integration of design and control for enterprise-wide sustainability. Computers and Chemical Engineering, 132,106610

[10] Bridger.J, 1999. Toward an Interactional Approach to Sustainable Community Development. Journal of Rural Studies: 15(4).

[11] Wood, D., 2010. Measuring corporate social performance: A review. International Journal of Management Reviews. 12/1: 20-32.

[12] Gossling, T and Vocht, C., 2007. Social role conceptions and CSR policy success. Journal of Business Ethics. 47/40: 363-372.

[13] Carroll, A. B., 1991. The pyramid of corporate social responsibility: Toward the moral management of organizational stakeholders. Business horizons. 34/4: 39-48.

[14] Duygu. T, 2008. Measuring Corporate Social Responsibility: A Scale Development Study. Journal of Business Ethics, 85, 411-427.

[15] Imran. A, 2010. Effects of Motivational Factors on Employees Job Satisfaction a Case Study of University of Punjab. International Journal of Business and Management, Vol.5, No.3.

[16] Quintero-Angel, M., Peña-Montoya, C. C., Fajardo-Toro, C. H., \& Aguilera-Castillo, A (2018). Opportunities and Challenges for Sustainable Business Strategic Planning in Small and Medium Enterprises (SMEs). In Green Production Strategies for Sustainability (pp. 153-167).

[17] Farsi, J. Y., \& Toghraee, M. T (2014). Identification the main challenges of small and medium sized enterprises in exploiting of innovative opportunities (Case study: Iran SMEs). Journal of Global Entrepreneurship Research, 4(1).

[18] Le Ngoc Nuong, 2018. Factors affecting the development of small and medium industrial enterprises in Thai Nguyen-Viet Nam, Economic and Business Management University.

[19] Shivani Agarwal, Anjali Jindal, Pooja Garg, \& Renu Rastogi (2017). "Influence of Quality of Work Life on Trust - Empirical Insights from a SEM Application", The Journal of Indian Culture and Business Management, Vol 15, No. 4, pp. 506-25(ISSN 1753-0806)

[20] Phan Van Dan, 2012. Building a scale for enterprise sustainability, Scientific Journal, Can Tho University

[21] Ibrahim. U, 2008. An analysis of strategic factors affecting the performance of small and medium industries in Borno State of Nigeria. St Clements University, Nigeria.

[22] Bouazza. A, 2015. Small and Medium Enterprises as an Effective Sector for Economic Development and Employment Creation in Algeria, International Journal of Economics, Commer, Vol.3 (2). 